\title{
Cultural Grounds of Corruption in Russia
}

\author{
Natalia P. Kopsteva* \\ Siberian Federal University \\ 79 Svobodny, Krasnoyarsk, 660041, Russia
}

Received 12.06.2014, received in revised form 02.08.2014, accepted 15.10.2014

A subject of the research is the strategies of corrupt behaviour of the modern Russians and possible cultural grounds of these strategies. Having analyzed modern theories of the corrupt behaviour and cultural texts of Soviet writers, filmmakers, contemporary Russian writers we found cultural grounds of social communications rooted in an archaic and traditional Russian cultural space. Modern Russian social communications include cultural practices associated with giving and feasting. The difference between the strategies of the corrupt behaviour and cultural practices of giving and feasting is fundamental and should be considered in the modern Russian social management. Methodology of the study is related to the conceptual analysis of texts of cultural anthropologists, including those who study the economic and social aspects of giving. We applied hermeneutics of cultural texts, art representatives of the Soviet mythological world view and the Russian national image of the world. Scientific novelty of the study involves identifying interdependence between the Soviet mythological world view, the Russian national image of the world and the economic and social communications of giving and feasting. It is shown that the legal mechanisms to overcome the negative consequences of the corrupt behaviour are insufficient. It is necessary to introduce cultural practices based on the archaic and traditional values transformed to the new social communications and new strategies of social management.

Keywords: cultural studies, social communications, Russia, corrupt behaviour, Soviet cinema, Soviet literature, contemporary Russian literature, gift economy, social management, cultural practices.

Research area: Theory and History of Culture.

\section{Approaches \\ to understanding corruption}

According to "Transparency International", an international non-governmental organization that, since 1996, has been publishing the Corruption Perceptions Index, corruption is the abuse of entrusted power for private gain. In 2013, Russia ranked 127 with 28 points out of a possible 100. This index shows the frequency of corruption-related crimes, especially bribery and their volume. On March 8, 2006, Russian
Federation ratified the UN Convention against Corruption, and made a series of commitments to the implementation of international anticorruption mechanisms in all kinds of social practices, especially in the legal practice. In 2012, the Russian Prime Minister Dmitry Medvedev approved the National Anti-Corruption Plan for 2012-2013. Every day a significant number of highprofile anti-corruption cases are covered with the federal and regional media. Many experts believe that corruption in Russia is part of its economic

(C) Siberian Federal University. All rights reserved

* Corresponding author E-mail address: decanka@mail.ru 
and political system. Some experts bring their estimates to extremes and say that corruption in Russia is a hidden essence of its current system. Some Russian sociologists suggest that the Russian citizens consider measures taken by the State insufficient. Thus, according to the Sociological Services of the Anti-Corruption Foundation $31.9 \%$ of Russians believe that the level of corruption in Russia is not reducing, but growing..

However, there is another side to information about the crimes of corruption in Russia. In the information war that accompanies the new forms of social conflicts in the global community, battles for cultural (ethnic, religious) identities, persistent reports of corruption crimes may be part of a fierce political war, including a transnational economic competition.

Scylla and Charybdis for fighting corruption in Russia is the real harm to the social organism from corruption-related crimes and no less real destruction of the positive Russian cultural identity, when images of "Russia" and "corruption" combine in the public mind with the help of information technology. In recent years, publications with typical headlines have been emerging: "Is it possible to fight corruption in Russia", "Russia and corruption: Which one wins?" Ten years later", "Russia - corruption. Ideological confrontation", "There is no real fight against corruption in Russia", "Corruption in Russia: from customs and traditions to the way of life?", "Institutional corruption in Russia", "Corruption in Russia is a system", "Corruption in Russia. Russia in corruption: Is there a way out?" These are the headlines of scientific articles. Daily headlines in the media are much more expressive and emotional.

Reaction to the explicit and implicit identification of the Russian cultural identity and corruption as the economic, political and social evil is quite interesting. In one case, there are assertions of "eternity" of corruption, its rootedness in any state machine. For example, the following statement: "Corruption is a constant companion of government institutions originated centuries ago. As a socially negative phenomenon in society corruption has always existed, since the administrative apparatus has been formed, and was common to all states in all stages of their development". In the work "Corruption, Culture and Markets" S.M. Lipset and G.S. Lenz accepting a thesis about the ubiquity of corruption believe that its extent may be different in different types of states.. In another case, we consider the historical forms of corruption in Russia starting from feeding voivodes to bureaucratic corruption in the time of Nicholas II. In the third case, corruption appears as a global phenomenon typical of modern societies in any region of the world.. In the context of the Russian cultural identity corruption is seen as a tool in acute political debates at all levels of Russian political life - from federal to rural, from regional to municipal. A theoretical study of justification of corrupt practices in the processes of Russian cultural identification and self-identification is relevant, because 1) it helps to understand the origins of the corruption behaviour in a particular society; 2) it contributes to the demystification and self-awareness of Russians, 3) it indicates the vectors of cultural policy, specific mechanisms of the "soft power" that reduce corruption as a form of social existence.

Is it possible that at a certain stage of development of Russia the corrupt practices would receive a hidden social approval? If corruption is inherent in all the countries with transition economy, then is there a special situation in Russia, where corruption in any of its forms is included in the cultural values? J. Hellman, G. Jones and D. Kaufmannbelieve that theproblemofcorruption in the countries of Eastern Europe, where a new economic environment is being formed, is solved 
when the economic liberalization takes place rapidly and completely. Reasons for corruption in these countries, according to the researchers, are in economic behaviour. Corruption is a reaction of new participants of the market process who believe that their property rights in the new economic environment are not adequately protected.. Here, corruption is seen as a specific behavioural strategy, which the authors called the "State Capture". The researchers believe that the "State Capture" will stop when this corrupt behaviour will cause the process participants too many moral issues, i.e. when a developed civil society get involved in the process as a third power.

How does the business culture of Russia contribute to the prosperity of this form of the corrupt behaviour? It is clear that the market participants who choose this form of behaviour get some competitive advantages over other market participants whose behaviour is different. T.A. Nestik believes that there is no special Russian specificity here and that such corrupt behaviour gives economic subjects competitive advantages in all the countries with transition economy, where, previously, the economy of supremacy of the state over economic processes was prosperous. In the work of T.A. Nestik "Corruption and Culture" there is the author's clear understanding of the interconnection of deep cultural norms and values on the one hand, and the choice of the corrupt behaviour as an economic and political behavioural strategy, on the other hand. Thus, I. Klyamkin and L. Timofeev in the book "Shadow Russia" state that the Russian society is gradually identifies itself with the shadow economy, that at least $40 \%$ of the respondents confirm a direct or indirect involvement in the corruption process. This means that the schemes of the corrupt behaviour have a deep cultural base, without understanding of which the corrupt behaviour is almost ineradicable in certain societies.
For example, T.A. Nestik makes an interesting point. In addition to the behavioural strategy "State Capture" there is the second strategy of the corrupt behaviour that is the "Influence on the State", where the basis of an economic competitive advantage are strong and lasting business and personal relationships, longterm mutual relationship. So the studies show that certain economic subjects always choose one of the two corrupt behavioural strategies - either the "State Capture" (new, "young" business structures) or the "Influence on the State" ("veterans" of the business processes). But they never choose both strategies simultaneously. It also proves that for every choice of behavioural strategies there are specific and clear stable systems of cultural values that are not compatible with each other, which is perfectly understood by all participants of the business processes.

Even if the various countries and agents equally have a negative attitude towards the corrupt behaviour as a whole, they may differ with respect to the degree of seriousness of the corrupt behaviour. Thus, in the study Sanja Kutnjak Ivkovic policemen of three countries - Hungary, Finland and the United States - expressed their attitude to corruption actions and to the seriousness of each of these actions. And if the general attitude towards corruption was equally negative, the degree of seriousness of a particular act of corruption was evaluated very differently by the representatives of each country.

Lisa Cameron, Ananish Chaudhuri, Nisvan Erkal conducted a cross-cultural study of attitudes towards corruption misdemeanours (including bribery) in Australia, Indonesia, Singapore and India. Their findings also suggest that the attitude towards corrupt behaviour has a great cultural specificity. Thus, residents of India showed the greatest tolerance to corruption, the inhabitants of Australia - the least. However, the index of tolerance to corruption in Singapore 
and Indonesia also proved to be quite high. According to the position of S. Harrington, who believed that corruption increases during periods of modernization, the study authors conclude that the greater tolerance to corruption is peculiar to those countries that are undergoing institutional changes. However, the authors put down the stability of bribery exceptionally to the cultural specificity.

John Hooker comes up with a paradoxical conclusion that the anti-corruption actions typical of Western countries can destroy the cultural foundations of other societies and other countries. In the article "Corruption from a Cross-Cultural Perspective", he argues that the statements of claim in the courts, strict compliance with the conditions prescribed in the contract, which is characteristic of Western societies, destroy a cultural base of Japan, Taiwan, India, Korea, Middle East countries. Such studies are needed not only to understand the mechanisms of the corrupt behaviour, but also for understanding the deeper functioning mechanisms of the culture itself.

Corruption has a strong cultural foundation. This means that in addition to the economic environment the origins of the corruption behaviour are laid in all the cultural processes that underlie the processes of cultural identification and self-identification. I assume that the same cultural codes contain both tolerance and acceptance of the corrupt behaviour, and the possibility of denying this behaviour as a cultural standard.

\section{Attitude to corruption}

\section{in the artistic works of Russian writers and filmmakers}

At first glance, the attitude towards the corrupt behaviour in the literary works of Russian writers corresponds to the cultural European standards. It is negative. Characters with features of the corrupt behaviour are pictured satirically. For example, a character in the A.S. Griboyedov's comedy "Woe from Wit" named Famusov with his innocent remark on civil service: "Well, I cannot help but pay attention to a close friend" is characterized as a representative of the "old world", as a "conservative" in school textbooks on literature. And another character, the lover of Famusov's daughter, Sophia, Molchalin, who apparently chooses the strategy of the corrupt behaviour "Influence on the State" is also being evaluated negatively, especially in comparison with Chatsky who appears as a "victim" of the characters presenting the "old world".

This "old world" is full of corrupt officials of all stripes in the N.V. Gogol's comedy "The Inspector General". Actually, all the story lines of this comedy are associated with different strategies of the corrupt behaviour: "State Capture", "Influence on the State", "Administrative Corruption". The same with the numerous inhabitants of the world of the poem "Dead Souls" that are like a huge spider web-like social network connected and tied by strategies of the corrupt behaviour "Influence on the State". Gogol's world is a dark side of the huge "brotherhood" linking towns, estates and small estates of the owners of the land of the Russian Empire by millions of relations in the city.

And in the early works of F.M. Dostoevsky nasty characters are flesh and blood of this dark world. For example, an anti-hero of the novel "The Insulted and Humiliated", Prince Valkovsky, uses all his "Influence on the State" to humiliate and destroy his landlord Ikhmenev. Personal evil of prince Valkovsky combines both psychologically perverse qualities and a social dark position. It is truly a "prince of this world".

But it was the "other" justice that M.Yu. Lermontov threatened "murderers" of Alexander Pushkin, the "other" judge who "is not appealed to a clank of gold". But this "eternal judge", 
whose inhabitation is not "our" world, but a space where there is no time, where "thoughts and deeds are known in advance". In accordance with the philosophy of the romantic "world duality", Lermontov contrasts the earthly world of corruption and evil-speaking with the eternal world of the righteous justice and the inevitable triumph of truth.

One might have expected that in satirical works of the first years of formation of the Soviet literature in the 20 's of the $20^{\text {th }}$ century denunciations of corruption as a "tsarist vestige" would be numerous, and mobilization for a battle with the vestiges of corruption would be active and assertive. However, the image of a bribe taker and other varieties of corrupt officials in the Soviet literature was insignificant. Despite the fact that Russian literature of the $19^{\text {th }}$ century was seen as a carrier of aesthetics of the "critical realism" in the Soviet study of literature, bright and lurid images of bribe takers in the works of A.P. Chekhov, M.E. Saltykov-Shchedrin, A.V. SukhovoKobylin, A.N. Ostrovsky go into full compliance with a thesis of the state ideological concept that the Soviet state is a state where the power belongs to the "workers and peasants" so "the State Capture" or the "Influence on the State" in a Soviet myth belongs to the "past", but not to the "present" time and, surely, not to the "future". It would seem that a man like a character from A.S. Pushkin's novel "Eugene Onegin", a retired councillor Flyanov, characterized by the author as "a glutton, a bribe taker and a fool" is nonexistent in the Soviet community.

But the impossibility of corrupt officials in the Soviet society is a purely mythical feature, since contemporary scholars believe that corruption as a phenomenon is an inevitable aspect of the State system. Despite the fact that in fiction literature corruption was presented only in the form of "bribery", the criminal liability for corruption offenses was introduced in the Soviet Russia in
1918 and had been constantly increasing during $20-90$ 's of the $20^{\text {th }}$ century. In 1974 , the film directed by Sergei Mikaelyan "Premiya" [Bonus] (for which the director received the State Prize of the USSR (1976)) based on the play "Minutes of one meeting" by Alexander Gelman was released. Besides, the play by Alexander Gelman was put on at the main and the best theatres in the Soviet Union - the Moscow Art Theatre (director Oleg Yefremov) and the Bolshoi Drama Theatre (director Georgy Tovstonogov). Such attention to the work of art (12.9 million viewers only in movie theatres, and then there was a television version of the film, performances based on the play by A. Gelman "Minutes of one meeting" were also broadcasted on Soviet television) could not be accidental. The viewers were immersed into a mythical Soviet space where the most terrible crime of corruption in the Soviet society was a "bonus" intended for the work that a group of workers never did. A dramaturgic conflict was due to the refusal of the main character (working group leader) from the illegal bonus. With the help of vivid emotional conflicts, when the group leader shows the highest economic and cultural consciousness refusing from the illegal bonus and going through punishment by the heads of the construction work, the Soviet audience received information that even the "lightest" corruption offenses are, nevertheless, for the benefit of workers (in this case - the construction working group), but on the other hand, the socialist consciousness of the working people (construction workers) was formed so completely that it is capable of self-organization without the intervention of the state judicial system.

However, the poem by Vladimir Mayakovsky "Bribe Takers", the play by Alexander Gelman "Minutes of One Meeting" and the feature film by Sergei Mikaelyan "Bonus" (where the main character is played by the popular actor Yevgeny Leonov) are the artworks, where the corrupt 
behaviour of the Soviet people is condemned by direct messages, simple denials, negative emotions associated with the condemnation of the corrupt behaviour.

The Vice-President of the Free Economic Society, Kemer Norkin, in the book "Systemic Problems in the Fight against Corruption" proves indissoluble cultural and economic links between paternalism and corruption. One of the chapters of this book is called "Paternalism as the Main Cause of the Indestructibility of Corruption in Russia". In the article "Illusions of paternalism" Kemer Norkin defines paternalism as the totality of the social support provided by the public authorities to citizens of the state.. Kemer Norkin sees the origins of corruption in the centralized paternalistic state in the formation of united and huge financial flows of the state aid, when administrators of these flows (the article mentions the governors of the poorer Russian regions) skilfully direct a portion of the financial resources for personal purposes unrelated to the social support of those in need.

However, the economic paternalism also has cultural grounds associated with the specifics of social communications of the traditional (preindustrial) society. Protection that the elite has for those who are "below" and those who, for one reason or another, are "in trouble" has the most positive ethical semantic contexts in the Russian artistic culture, including literature and cinematograph.

At the end of the cult film "Heart of a Dog" directed by Vladimir Bortko and delivered based on the novel by Mikhail Bulgakov, professor Preobrazhensky wanting to get rid of the "people's control" and the "House Committee" calls his powerful patient (in the film it was a man with a Georgian accent and other features that made it look like it was Stalin) and urges him to save him from the tedium of members of the House Committee. Thus, the climax of the film is a rather "original" cultural signal. Only calling for protection of a strong and powerful statesman ("Petr Aleksandrovich") can resolve the accumulated contradictions and pacify conflictive social communications that, without this intervention, would lead to the persecution of the outstanding scientist and end his scientific and medical work in Soviet Russia.

Thus, personal patronage of the influential government official not only has a positive ethical value for the outstanding scientist and a doctor, but also is a certain cultural model of social communications characteristic for the traditional Russian cultural space. In mythology created in the Soviet literature and in the Soviet cinema, the deus ex machine method when the long-running conflict was resolved with the help of the "wise" decision, protection and the incredible moral force of a person "possessing power" (usually a party functionary, a "party organizer") was used often enough. So often that we can speak of its special role in the mythological space-time of the Soviet social communications.

Mythological significance of the "party organizer" in the Soviet mythological world view is disclosed in the article of Darya Zemskova "The Party Organizer as a literary character". According to Darya Zemskova, the Party Organizer is a universal mythological character of the Soviet literature, its Hero, the Spiritual Father. "The Party Organizer (political worker, commissioner) or the Komsomol Organizer (in a novel, where the main character is a Komsomol) is a mandatory figure in a canonical social realistic novel. The main objective of the Party Organizer is to "advise, instruct, teach" ("Roots and Crown" by V. Kozhevnikov). He carries out the ideological work. He raises the power of the spirit, leads the lost, and enlightens the desperate". Let us add that the Party Organizer is often the Saviour who appears at the climax of a complex conflict, great tension, contradiction 
between a personal and public interest (as is well known, the "main" artistic contradiction disclosed in works created by the method of socialist realism). For example, such a Party Organizer was Zakhar Bolshakov, the character of the novel by Anatoly Ivanov "Shadows at Noon", the cinematic image of which was created by the actor Petr Velyaminov.

In the article "A Short Course in Paratheory of the Soviet cinema" Victor Mathiesen also believes that the "Party Organizer" is "Ilya Muromets" of the Soviet cinematograph, the God of Machines, the unexpected saviour. He also compares the mythical Soviet "Party Organizer" with a magic helper of fairy tale characters who get "meaningless" and undoable tasks that only the assistant of the super-natural world could help to do..

Thus, in the universal Soviet mythological world view there was a character that had the highest social status (not economic, but political and ideological one) that a Soviet person could only have. This character was intended to ensure that all the other good characters in the moment of need could ask him for the most complex and incredible help that he always provided. Some characters-party organizers provided this help not even at the request of the workers, but because of their own omniscience and omnipotence. At the climax they found themselves in the right place at the right time when the long-running conflict reached a deadlock. In the novel by Vsevolod Kochetov "Regional Committee Secretary" and in the film of the same name by Vladimir Chebotarev (1963) not just a "Party Organizer", but a "Regional Committee Secretary" carries a mission of the heroic and even mythological divine salvation. After the release of the film the image of the "Regional Committee Secretary" took a firm place in the hierarchy of party heroessavers to help the characters in complex internal and external circumstances of their lives.
And if with the help of direct cultural text messages the corrupt behaviour was rejected and stigmatized as criminal, the paternalistic heroic images were formed in the cultural texts that had the opposite content. Complex internal and external conflicts are resolved not in the process of application of advanced social technologies of managing complex human groups, but using traditional cultural technologies of patronage. The image of the Soviet people as a "Big Family" was based on the traditional cultural ideals, but the same image of the great family played Old Harry with the builders of the new socialist society. The high moral authority of the hero-party organizer was a different form corresponding to the higher social status of the spiritual leader of the clan. It was not a new socialist model that was implemented in social psychology of the Soviet society, but an ancient model of traditional clan relations. It is on this ancient model of cultural standards of social communications that the current stereotypes of the corrupt behaviour of Russian citizens hold.

Thus, an ideological objective of the builders of a socialist society to change the corrupt behaviour strategies of the Soviet people was not fulfilled. To solve this problem, the simple text messages condemning criminal forms of the corrupt behaviour were used. At the same time, in the Soviet mythological worldview there was a figure of the party organizer (Komsomol organizer, District Committee Secretary, Regional Committee Secretary, etc.) as a good character-saviour that did not overcome, but consolidated forms of paternalism characteristic of traditional societies. A carrier of higher moral qualities, a hero-saviour-party organizer played the personification of the forces that interfere with the complex existential situations of other mythological characters and solve the incredibly complex problems of social communications. Without the help of this mythological hero- 
mediator in the Soviet mythological worldview no complex social and communicative conflict, no artistically manifested contradiction could be solved.

Current strategies for the corrupt behaviour of Russian citizens rely both on traditional paternalism of the pre-industrial society and its artistic modelling in the Soviet mythological worldview fixed in the relevant signs, images, symbols, in a variety of cultural texts.

\section{Representations of "The Accursed Share" by Georges Bataille \\ in the traditional Soviet culture, alcoholization and the corrupt behaviour}

In the current economic, social and cultural studies there us a term "gift economy". We are talking about the economy, the subjects of which do not create a funded part or a capital as a result of an economic exchange. Gift economy differs from the market economy. At the same time, it differs from barter economy. Value of the gift is determined by the personal attitude of the giver and the receiver towards this gift. One of the first researchers who described gift economy was Bronislaw Kaspar Malinowski. He studied traditional societies living on The Trobriand Islands.

A contemporary anthropologist, Jonathan Perry, believes that the gift economy in the contemporary studies is discussed as if it is present in all the local cultures, as if it is a kind of a cultural universal, an anthropological principle. But J. Perry also points out that the gift economy is not a universal economic principle at all. There is no universal economic practice of giving. The exchange of gifts is implemented in many different ways in local cultures. And the gift economy in one of the local culture is fundamentally different from the gift economy in another local culture. Chris Gregory also believes that the exchange of gifts is not so much an economic principle as an inseparable part of certain political, tribal, religious, social institutions.

Talking about the history of the study of the gift economy, you cannot go past the classic work of the famous French anthropologist Marcel Mauss "Essay on the Gift. Form and Grounds of the Exchange in Archaic Societies". In this work, Mauss pointed to the main purpose of the exchange of gifts, which is the establishment of reciprocity, participation. The exchange of gifts has a moral sense in the first place, an economic sense - in the second. A subject that makes the greatest gifts ranks highest in the social stratification. Marcel Mauss and Chris Gregory believe that the exchange of gifts creates reciprocity of friendship and enmity. A complex system of giving organizes all the basic social relations, both positive and friendly for participants in this process, and negative and hostile. Thus, the exchange of gifts is a form of the establishment of social solidarity that is present both in traditional societies and in the modern societies.

A French thinker Georges Bataille in his famous book "The Accursed Share" reveals the most important irrational grounds of social solidarity. He reveals the crucial meaning of the social balance, social harmony for the archaic and traditional societies. The archaic society that is very sensitive to disruption of the material and/or spiritual (semantic) balance immediately reacts to the first signs of an imbalance in any of its varieties: economic (excesses, extra cost, capital, savings, etc.), or the moral and spiritual (more effective social institutions and practices that can lead to excesses, imbalance, extra cost, etc.). Unnecessary things lead to more complex social relations, where the imbalance is growing and social solidarity corrodes with it. Ancient societies develop practices of sacrifices, joint feasts where excesses are periodically exterminated, given away to those who, on the contrary, need something. Inside these sacrifices 
and joint events, orgies, feasts the social statuses either get balanced or the highest status is given to those who gave away more than others.

There are numerous works on the history of economy and culture of giving in Russian history. In literary works of Russian authors, "easiness" of establishing solidarity in joint meals and alcohol drinking is reflected in different styles: from sympathy to sarcasm, from the tragic grotesque to the understanding empathy. In a wonderful novel by Tatiana N. Tolstaya "Distant Lands" from her new collection "Light worlds" the author writes:

"Meanwhile - who am I to tell you? - A sad Russian man sitting alone at the bar, unrepresentable. Having come to a place to have a drink, he immediately looked for the company and immediately got attached to her and entered into a fast, short and dangerous friendship treading on everyone's feet and breaking all the private barriers that fellow drinking buddies even did not know about.".

In the contemporary Russian national worldview collective solidarity and mutual trust develop in joint feasts. From the point of view of the Russian national morale, people who sit at one table and "drink" (i.e., they drink alcoholic beverages) can not harm each other either at the very moment of the feast or in the future, as well as in the probable future where they will have some kind of cooperative business, political or other social interests.

I remember the "explanation" of one middle-aged woman from Krasnoyarsk, when she told me why a company she worked in as a cashier went broke. "Our company went broke because the owner did not drink and did not go to baths with the guys. Because our men decide all the important things while drinking in baths." She had no doubt that competitors destroyed the company where she worked, because the owner did not participate in the national social rituals preventing hostility and fraud. Baths is a place where people take off their clothes, thus they are the most open to each other. They drink weak or strong alcoholic beverages and thus open to each other not only their bodies but also their emotional outbursts, disclose their secret flows of their mental life. The resulting trust is so strong that it turns into a foundation of strong business relationships, or at least guarantee a priori friendliness, it acts as an unwritten law, an unofficial contract.

This specific business culture does not disappear in modern Russia, but gets stronger. In the Russian market there are many leisure offerings for business partners, strange people, and potential employees. They can participate in joint fishing, visit various baths, saunas, bars, buffets, travel to a variety of recreation facilities to demonstrate trust in each other and create an arrangement that is much stronger than any legal contract. Joint feasts not only complete and reinforce the agreements, they are a guarantee that their participants did an excellent job in the past and will also be good in the future with all the challenges they face.

This mood is represented through in a quite striking manner in the verses of the famous poetbard of the Soviet Russia Yuri Vizbor:

But we met dawns in seas so many times

And drank alcohol wandering between the ice floes.

We will lose everything through drinking, but will never disgrace the fleet,

We will go through everything, but will never shame the fleet.

The semantic series "will lose everything through drinking - will never disgrace", "will go through everything - will never shame" were perceived by listeners of these verses as a matter of course. Joint feasts in the mythology of the Russian and Soviet mythology are a space of higher trust in each other and a space to enter 
into the strongest agreements and the most indestructible mutual obligations.

In the contemporary Russian legislation many explanations are related to the difference between bribes and gifts. There is the special Article 572 of the Civil Code that determines the difference between a gift and a bribe as "gratuitous" of the gift and a personal gain of a bribe taker. In the legal practice, however, this difference was reduced to determining the value of a gift and/or a bribe. Things worth up to 3,000 rubbles are considered to be gifts, and things that cost more than 3000 rubbles can be defined as a bribe, if it is a gift or a bribe to a state or municipal official.

However, the legal regulation of social relations in contemporary Russia fails where ancient rituals are performed, the origins of which lie in the depths of Russian ethnic culture. Destruction of social communications, in which a mediator-representative is a gift and especially a gift that is associated with participation in the joint feasts, is impossible without destroying a specific ethnic cultural practice.

In the collection of short stories "Do not get in the car where there are two" a famous Russian writer whose works have become classics, Lyudmila S. Petrushevskaya, published a work that is consonant with many of her other works in stylistic features, choice of characters, and a story line. But its unusual title - "Goddess. A physiological essay" - brings to mind the style of Russian critical realism, where a genre of a physiological essay was basic. However, the writer does not use the concept of a physiological essay directly. With a tragicomic and even sentimental, grotesque irony characteristic of all of her works she creates a philosopho-literary generalized image of Russian national religion - worship of the Goddess that requires self-destruction through drinking vodka and/or similar strong drinks. In the artistic representation of Lyudmila
Petrushevskaya this cult is professed by men; women also die for the sake of the Goddess, but more indirectly, through the terrifying and miserable existence created by men who zealously serve the Goddess.

I've been writing a story of the people I love and consider as the apex of creation. They left and will leave unknown; not only will they leave as scrubby elderly people who are ashamed of themselves and the fact that they are a burden. But their kindness and awareness of insignificance of all the material wealth, their royal indulgence, tolerance to people makes me cry over their lives, over life in general. Over the Russian life, in particular. For here is a great mystery of the Russian soul: self-disengagement from the welfare of this world. Apparently (bells ringing), our people are so perfect that they do not want this perfection, they kill and waste it. They do not glean it for millennia (glory, glory) like the Japanese, the Dutch or the Luxembourgers do, they do not multiply it from generation to generation (crescendo), but they waste it, shake off their fingers, brush away as dust. Amen. For the same millennia. And they should have disappeared from the face of the earth a long time ago, if they had not happened to become so rich. Glory!

For many centuries Russian literature created by Lyudmila Petrushevskaya creates philosophical generalization, reveals what George Gachev called the "national image of the world". Only the national image of the Russian world that found its true essence of an artistic word reveals deep irrational social forces behind the everyday existence of the Russian people.

If you simply declare the culturally specific behaviour as criminal and subjected to eradication, then not only it will not bring 
positive results, but will rather destroy deep cultural layers. So, Lyudmila Petrushevskaya noticed that this worship of the Goddess is a special difference between men and women in the Russian cosmos. Therefore, if we admit that the corrupt behavioural strategies of joint "feasting" before making important business decisions are criminal, the boundary that separates the Russian men from the Russian women will be shaken. The cult of a "man" characteristic for the Russian national world view will not allow it to happen. So these behavioural strategies will not disappear. Legal laws to prohibit such forms of behaviour will not work, once again illustrating a modern Russian proverb that punitive severity of the current Russian laws is compensated by not having to follow them.

Therefore, on the basis of the archaic cultural practices we need to build modern cultural practices that would not deny social communications of giving-feasting directly, but, on the contrary, would approve other similar ancient, cultural practices that are focused on the results even more important than the practices of feasting-giving.

Honour, conscience, righteousness, justice are the key concepts of the Russian national ethics that need to be preset in the modern practices of social communications. Ancient archaic practices of giving-feasting should be used as often as possible in the "light" space of public communications. The more social communications will be mediated by givingfeasting in its light, day, visible dimension, the less time and effort remain for them in the dark, night, chthonic dimension of these communications.

There will never be enough direct legal mechanisms to fight the corrupt behaviour in the Russian society. Only inclusion into the everyday social communications system of the ancient forms of national solidarity and filling these ancient cultural practices with positive social solidarity objectives will help to overcome criminal forms of modern Russian corruption.

\section{References}

1. Akimova, N.V. Istoki korruptii i osobennosti borby s neyu v Rossii XIV-XVII vekov [The origins of corruption and specifics of fighting it in Russia in the $14^{\text {th }}-17^{\text {th }}$ centuries] History of State and Law. 2008. № 8. P. 17-19.

2. Azhirbaeva, O.R. Protivodeistviye korruptsii v politseiskikh vedomstvakh SSHA i Evropy [Fighting corruption in police departments of the United States and Europe] Bulletin of the South Ural State University. Series: Law. 2006. No 13. P. 12-16;

3. Babenko, V.N. Korruptsiya v Rossii: ot obychayev i traditsii - k obrazu zhizni? [Corruption in Russia: from customs and traditions to the way of life?] Russia and the modern world. 2009. № 4. P. 44-61.

4. Barsukova S.Yu., Naumov Yu.G., Kolesnikov V.V. institutsionalnaya korruptiya v Rossii [Institutional corruption in Russia. Economic subjects of the post-Soviet Russia (institutional analysis) ten years later. Part 3: The Russian state. M.: MPSF, 2010. P. 39-76.

5. Bataille, G. The Accursed Share. Sacred sociology. M.: Ladomir, 2006. 742 p.

6. Bukharov A.V., Zinov V.G., Kirko V.I. Ob innovatsionnoi structure universitetskikh komplektov [On an innovative structure of the university sets] Innovations. 2008. № 7. P. 38-43.

7. Fedorkin N.S. Politicheskaya kultura i korruptsiya: grani sovmestimosti [Political culture and corruption: the verges of compatibility] Bulletin of Moscow University. $18^{\text {th }}$ Series. Sociology and Political Science. 2008. № 3. P. 35-47. 
8. Gregory, Chris (1982). Gifts and Commodities. London: Academic Press.

9. Grigorova T.V. Korruptsia v Rossii: istoriya i sovremennost [Corruption in Russia: Past and Present] Siberian financial school. 2009. №1. P.47-51.

10. Hellman J.S., Jones G., Kaufmann D. Seize the State, Seize the Day: State Capture, Corruption and Influence in Transition //World Bank Policy Research Working Paper № 2444. September 2000.

11. Hooker John. Corruption from a Cross-Cultural Perspective. URL: http://ba.gsia.cmu.edu/ jnh/corruption08s.pdf (October, 2008).

12. Ilbeykina M.I. Vizualno-antropologicheskaya spetsifika sovremennykh kulturnykh praktik [Visual and anthropological specificity of contemporary cultural practices] Contemporary problems of science and education. 2013. № 3. P. 452.

13. Karlova O.A., Koptseva N.P., Kirko V.I., Reznikova K.V., Zamaraeva Yu.S., Sertakova E.A., Kistova A.V., Pimenova N.N. and others. Novoye budushcheye Sibiri: ozhidaniya, vyzovy, resheniya [New Future of Siberia: expectations, challenges and solutions]. Krasnoyarsk: Publishing House of the Siberian Federal University, 2013.

14. Kirko V.I., Bukharov A.V. Innovatsionnaya deyatelnost i nauchno-tekhnicheskiy marketing [Innovation activity and scientific and technical marketing] Prospective materials, technologies, constructions, economics. Proceedings of the All-Russian Scientific and Technical Conference. May 25-27, 2000. Edited by V.V. Statsura. Part 2. Krasnoyarsk, 2003. P.2.

15. Kirko V.I., Zakharova K.N. Traditsionnaya khozyaistvennaya deyatelnost etnosokhranyayushchiy obraz zhizni [Traditional economic activity - a lifestyle to preserve ethnos] The Arctic and the North. 2013. № 12. P.24-31.

16. Kirko V.I., Bukharov A.V., Keush A.V. Otsenka innovatsionnogo potentsiala tipovykh administrativno-territorialnykh obrazovaniy Krasnoyarskogo kraya [Evaluation of innovative capacity of typical administrative-territorial units of the Krasnoyarsk Territory] Innovations. 2010. № 12. P. 78-83.

17. Kirko V.I., Kopitsa A.S., Upatov A.V. Otsenka urovnya kachestva i polnoty okazaniya meditsinskoy pomoshchina territorii Taimyrskogo Dolgano-NenetskogoiEvenkiyskogo munitsipalnykh rayonov Krasnoyarskogo kraya [Evaluation of the level of quality and fullness of medical care in the territory of Taimyr Dolgan-Nenets and Evenk municipal districts of the Krasnoyarsk Territory] Modern problems of science and education. 2013. № 2. P. 57.

18. Kistova A.V. Metodologicheskoye znacheniye "ponimayushchey germenevtiki" Vilgelma Dilteya dlya sotsialno-filosofskogo issledovaniya sovremennykh sotsiokulturnykh fenomenov [Methodological importance of "understanding hermeneutics" of Wilhelm Dilthey for the sociophilosophical study of contemporary social and cultural phenomena] Modern problems of science and education. 2013. № 3. P. 450.

19. Kistova A.V. Etnograficheskiy metod $\mathrm{v}$ sotsialno-gumanitarnykh issledovaniyakh [Ethnographic method in the social and humanitarian research works] Modern problems of science and education. 2013. № 6. P. 900.

20. Kistova A.V., Pimenova N.N., Zamaraeva Yu.S., Reznikova K.V. Research possibilities for studying the indicators of quality of life of indigenous peoples of the North (based on the study of indigenous peoples of the North of Russia). Life Sci J 2014;11(6s):593-600.

21. Kleiner V.G. Korruptsiya v Rossii. Rossiya v korruptsii: est li vykhod? [Corruption in Russia. Russia in corruption: Is there a way out?] Economic Issues. 2014. № 6. P. 81-96. 
22. Klyamkin I., Timofeev L., Tenevaya Rossiya [Shadow Russia]. Economic and sociological research. M.: Russian State Humanitarian University, 2000. P.224-225.

23. Kolesnik M.A. Spetsifika ponimaniya slova "Rodina" studentami Sibirskogo federalnogo universiteta [Specificity of understanding the word "Motherland" by students of Siberian Federal University] Modern problems of science and education. 2014. № 2. P.468.

24. Koptseva N.P. Kulturologicheskaya baza formirovaniya obshchenatsionalnoy rossiyskoy identichnosti v sibirskikh reginakh Rossiyskoy Federatsii [The cultural base of the formation of Russian national identity in Siberian regions of the Russian Federation] Bulletin of Volgograd State University. Series 7: Philosophy. Sociology and Social Technologies. 2012. № 3. P.11-15.

25. Koptseva N.P., Kirko V.I. Post-Soviet practice of preserving ethnocultural identity of indigenous peoples of the North and Siberia in Krasnoyarsk Region of the Russian Federation. Life Sci J 2014; 11(7):180-185.

26. Koptseva N.P., Libakova N.M. Produktivnost gendernogo podkhoda dlya gumanitarnykh issledovaniy [The productivity of a gender approach for the Humanities Research] Modern problems of science and education. 2013. № 1. P.400.

27. Korruptsiya v Rossii - eto sistema [Corruption in Russia is a system] Personnel Management. 2010. № 2010. P. 47.

28. Kovtun N.V. Patriarkhalnyi mif v traditsionalistskoy proze rubezha 20-21 vekov [A patriarchal myth in traditionalist prose at the turn of the $21^{\text {st }}$ century] Siberian Journal of Philology. 2013. № 1. P. 77-87.

29. Kovtun N.V. Sudba patriarkhalnogo mifa v izobrazhenii Borisa Yekimova ("Kholyushino podvorie", "Pinochet") [The fate of the patriarchal myth in the image of Boris Yekimov ("Holyushina's farm”, "Pinochet”) ] Russian Literature. 2013 Vol.73. № 3. P. 411-425.

30. Lashkov M. Rossiya - korruptsiya. Ideologicheskoye protivostoyaniye [Russia is corruption. Ideological confrontation] Sledovatel. 2008. № 10. P. 45-48.

31. Libakova N.M. Modifikatsii gendernykh obrazov v russkoy culture kontsa XIX - nachale XXI vv. [Modifications of gender images in the Russian culture of the late $19^{\text {th }}$ - early $21^{\text {st }}$ centuries]. Abstract of the PhD thesis. Veliky Novgorod, 2011.

32. Libakova N.M., Sertakova E.A. Metodologiya prikladnykh etnologicheskikh issledovaniy severnykh territoriyRossii: preimushchestva ekspertnogo intervyu [The methodology of applied ethnological studies of the Northern territories of Russia: the benefits of expert interviews] NB: Issues of society and politics. 2014. № 3. P.67-86. DOI: 10.7256/2306-0158.2014.3.11268. URL: http://enotabene.ru/pr/article_11268.html

33. Libakova N.M., Sitnikova A.A., Sertakova E.A., Ilbeikina M.I., Kolesnik M.A. Modern practices of regional and ethnic identity of the Yakuts (North Asia, Russia). Life Sci J 2014; 11(12):133140 .

34. Libakova N.M., Sitnikova A.A., Sertakova E.A., Kolesnik M.A., Ilbeykina M.I. Interaction of the Yakut ethnicity and biological systems in the territory of the Sakha Republic (Hordogoy settlement, Suntarsky District) and Krasnoyarsk Krai (Essey settlement, Evenks District). Life Sci J 2014;11 (6s):585-592.

35. Lipset S.M., Lenz G.S. Korruptsiya, kultura i rynki [Corruption, culture and markets]. URL: http://pavroz.ru/files/lipsetcor.pdf 
36. Lisa Cameron, Ananish Chaudhuri, Nisvan Erkal. Propensities to Engage in and Punish Corrupt Behavior: Experimental Evidence from Australia, India, Indonesia and Singapore. URL: http://www.nisvanerkal.net/corruption5b-Mar-9.pdf (February, 2009).

37. Luneyev V. Nastoyashchey borby v Rossii s korruptsiyey net [There is no real fight with corruption in Russia] Criminal Law. 2007. № 5. P. 104-108.

38. Luzan V.S.Mekhanizmyvzaimodeistviyagosudarstva, biznesaskorennymimalochislennymi narodami Severa, Sibiri i Dalnego Vostoka v usloviyakh globalnykh transformatsiy [Mechanisms of interaction between the state and business with the Indigenous peoples of the North, Siberia and the Far East in the context of global transformations]. NB: The problems of society and politics. 2014. № 3. P.50-66. DOI: 10.7256 / 2306-0158.2014.3.11297. URL: http://e-notabene.ru/pr/article_11297. html

39. Luzan V.S. Sotsialno-filosofskiy analiz dinamiki gosudarstvennoy kulturnoy politiki Rossiyskoy Federatsii [Socio-philosophical analysis of the dynamics of the state cultural policy of the Russian Federation]. PhD thesis. Krasnoyarsk, 2011.

40. Malinowski B.K. Argonafty zapadnoy chaste Tikhogo okeana [Argonauts of the Western Pacific Ocean]. M.: ROSPEN, 2004. 584 p.

41. Mathiesen Victor. Kratkiy kurs parateorii sovetskogo kino [Short course on Paratheory of the Soviet cinema] Art of cinema. 1993. № 9. P. 122-127.

42. Mauss M. Ocherk o Dare. Forma i osnovaniye obmena v arkhaicheskikh obshchestvakh [Essay on the Gift. A form and base of the exchange in archaic societies] Mauss M. Societies, an exchange, a person. M.: Science; The main edition of Oriental Literature, 1996.

43. Mizeriy A.I. Istoriya borby s korruptsiyey v Rossii [The history of the fight against corruption in Russia] Bulletins of N.I. Lobachevsky State University of Nizhny Novgorod. Series: Law. 2001. № 2. P. 182-189.

44. Modern methods of combating corruption. URL: http://www.ufmskrn.ru/site2/ protivodeystviekorrupcii/sovremennie_metodi.pdf

45. Mungiu-Pippidi A. Korruptsiya: problema kultury ili nepodkontrolnosti chinovnikov obshchestvu? [Corruption: a cultural problem or uncontrollability of officials?] Comparative Constitutional Review. 2003. № 2. P. 26-31.

46. Nestik T.A. Korruptsiya i kultura [Corruption and Culture] Sledovatel. 2008. № 5. P. 47-52.

47. Norkin Kemer. Illyuzii paternalizma [Illusions of paternalism. Electronic resource]. Access at: http://ecpol.ru/blog-portala/59-illyuzii-paternalizma.html. Publication date: 06.09.2012.

48. Norkin Kemer. Sistemniye problemy borby s korruptsiyey [Systemic problems of fighting corruption]. Electronic resource. Access at: http://korrossia.ru/research-work/10481-sistemnyeproblemy-borby-s-korrupciey.html. Publication date: 04.18. 2014

49. Parry, Jonathan (1986). The Gift, the Indian Gift and the 'Indian Gift'. Man 21 (3): 46669. DOI: $10.2307 / 2803096$

50. Petrushevskaya L.S. Boginya. Fiziologicheskiy ocherk [Goddess. Physiological essay] Petrushevskaya L.S. Do not get in the car, where there are two. Electronic resource. Access at: http:// petrushevskaya.livejournal.com/78020.html. Date: January 17, 2012.

51. Pimenova N.N. Kulturnoye naslediye korennykh malochislennykh narodov Krasnoyarskogo kraya i sovremenniye kulturniye praktiki [Cultural heritage of the Indigenous 
peoples of the Krasnoyarsk Territory and modern cultural practices] NB: Cultures and Arts. 2014. № 2. P.28-66. DOI: 10.7256/2306-1618.2014.2.11269. URL: http://e-notabene.ru/ca/ article_11269.html

52. Pozdnyakova O.A., Reznikova K.V. Osobennosti subyektov khudozhestvennoy kommunikatsii [Features of the subjects of the artistic communication] Modern problems of science and education. 2013. № 4. P.385.

53. Razumovskaya V.A. K voprosu ob unifikatsii nauki, iskusstva i perevoda [On the unification of science, art and translation] Proceedings of the St. Petersburg University of Economics and Finance. 2011. № 3. P. 32-36.

54. Razumovskaya V.A., Sokolovsky Ya.A. Universalnaya kategoriya izomorfizma i eye svoistva $\mathrm{v}$ lingvisticheskom i perevodsheskom aspektakh [A universal category of isomorphism and its properties in the translation and linguistic aspects] Proceedings of Krasnoyarsk State University. Humanities. 2006. № 3-2. P. 220-226.

55. Reznikova K.V. Znacheniye kinematografa dlya formirovaniya obshcherossiyskoy natsionalnoy identichnosti [Importance of cinematograph in the formation of the All-Russian national identity] Modern problems of science and education. 2013. № 3. P.416.

56. Reznikova K.V. Sotsialnoye konstruirovaniye obshchenatsionalnoy identichnosti v Rossiyskoy Federatsii [Social construction of national identity in the Russian Federation]. PhD thesis. Krasnoyarsk, 2012.

57. Reznikova K.V., Zamaraeva J.S., Kistova A.V., Pimenova N.N. The current state of traditional socio-cultural practices of indigenous peoples of the North (on the example of cultures of Selkups, Nenets and Essey Yakuts). Life Sci J 2014; 11(12):126-132.

58. Sanja Kutnjak Ivkovic, (2005) "Police (mis)behavior: a cross-cultural study of corruption seriousness", Policing: An International Journal of Police Strategies \& Management, Vol. 28 Iss: 3, pp. 546 - 566 .

59. Semenova A.A. Vizualnaya kultura modernizirovannogo sotsiuma [Visual culture of the modernized society] Bulletin of Volgograd State University. Series 7: Philosophy. Sociology and Social Technologies. 2012. № 3. P. 145-149.

60. Semenova A.A. Modifikatsii drevnerusskogo kontsepta "gosudarstvo" v rossiyskoy culture XXI veka [Modification of an ancient concept of "state" in Russian culture of the $21^{\text {st }}$ century] (methodological aspect). PhD thesis. Krasnoyarsk, 2009.

61. Seredkina N.N. K voprosu o metodologicheskikh printsipakh kulturno-semioticheskogo podkhoda $\mathrm{v}$ izuchenii iskusstva indigennykh narodov Severa, Sibiri i Dalnego Vostoka [On the methodological principles of the cultural-semiotic approach to the study of art of the Indigenous peoples of the North, Siberia and the Far East] NB: Culture and Art. 2014. № 2. P.127-146. DOI: 10.7256/2306-1618.2014.2.11320. URL: http://e-notabene.ru/ca/article_11320.html

62. Seredkina N.N. Konstruirovaniye pozitivnoy etnicheskoy identichnosti v polikulturnoy sisteme [Construction of positive ethnic identity in a multicultural system]. Abstract of the $\mathrm{PhD}$ thesis. Krasnoyarsk, 2013.

63. Seredkina N.N. Pravoslavniye obrazy v khudozhestvennoy etnokulture sovremennoy Sibiri [Orthodox images in the artistic ethnoculture of the modern Siberia] Modern problems of science and education. 2013. № 3. P. 417. 
64. Sertakova E.A. issledovaniya "goroda" v klassicheskikh issledovaniyakh zarubezhnukh uchenykh [Studies of a "city" in classical works of foreign scholars] Modern problems of science and education. 2013. № 4. P.381.

65. Sertakova E.A. Kulturnaya geografiya A. Lefevra v svete gumanitarnykh issledovaniy sotsialnogo prostranstva goroda [Cultural geography of $\mathrm{H}$. Lefebvre in the light of humanitarian studies of the social space of the city] Theory and practice of social development. 2012. № 3. P. 24-26.

66. Shakirov I.A. Problema sootnosheniya mezhdu kulturoy korruptsii i "kolichestvom" demokratii $\mathrm{v}$ gosudarstvakh paternalistkogo tipa [The problem of correlation between the culture of corruption and the "amount" of democracy in states of the paternalistic type] Bulletin of the Institute for Humanities Research of the Republic of Bashkortostan. Ufa, 2013 P. 187-197.

67. Skvachkov P.E., Nadvornaya N.N. Effektivniy mirovoi opyt borby s korruptsiyey [Effective world experience in fighting corruption] Scientific, Technical and Economic Cooperation of AsiaPacific countries in the $21^{\text {st }}$ century. 2012. № 3. P. 169-174.

68. Skvortsova E.A. Pravoviye mekhanizmy protivodeystviya korruptsii v stranakh Evropy [Legal mechanisms for fighting corruption in Europe] Bulletin of the Federal Arbitration Court of the Moscow District. 2013 № 2 (15) P. 128-133.

69. Solomenko E.V. Vozmozhno li pobedit korruptsiyu v Rossii [Is it possible to fight corruption in Russia] Topical problems of development of science and education. Collection of scientific papers based on materials of the International scientific-practical conference: in 7 parts. "Ar-Konsalt" Ltd., Moscow, 2014. P.8-12.

70. Talapina E.V. Rossiya i korruptsiya: "desyat let spustya". Kto kogo. [Russia and corruption: “ten years later”. Which one wins?] State Service. 2008. № 6. P. 16-28.

71. Tolstaya Tatiana. Legkiye miry [Light worlds]. M.: AST, 2014.

72. Zemskova Daria. Partorg kak literaturnyi geroi [Party organizer as a literary character]. Electronic resource. Access at: http://bi.narod.ru/s_s.htm.

\section{Культурные основания российской коррупции}

\section{Н.П. Копцева}

Сибирский федеральный университет Россия, 660041, Красноярск, пр. Свободный, 79

\footnotetext{
Предмет исследования - стратегии коррупиионного поведения современных россиян и возможные культурные глубинные основы этих стратегий. На материале анализа современных теорий коррупиионного поведения и культурных текстов советских литераторов, кинематографистов, современных российских писателей рассматриваются культурные основания социальных коммуникаций, укорененные в архаическом и традиционном русском культурном пространстве. Современные российские социальные коммуникации содержат культурные практики, связанные с дарением и пированием. Различие между стратегиями коррупџионного поведения и культурными практиками дарения и пирования имеет принципиальный характер $и$ должно быть учтено в
} 
современном российском социальном управлении. Методология исследования связана с концептуальным анализом текстов культурных антропологов, в том числе изучающих экономические и социальные аспекты дарения. Применялась герменевтика культурных текстов, художественных репрезентантов советской мифологической картины мира и русского национального образа мира. Научная новизна исследования связана с выявлением взаимообусловленности советской мифологической картины мира, русского национального образа мира с экономикой и социальными коммуникациями дара, пира. Показывается, что правовые механизмы преодоления негативных последствий коррупционного поведения недостаточны. Необходимо внедрять культурные практики, основанные на архаичных и традиционных иченностях, но трансформированные к новым соцчиальным коммуникациям и новым стратегиям сочиального управления.

Ключевые слова: культурные исследования, социальные коммуникации, Россия, коррупционное поведение, советский кинематограф, советская литература, современная российская литература, экономика дара, социальное управление, культурные практики.

Научная специальность: 24.00.01 - теория и история культуры. 